\title{
PEMANFAATAN AZOLLA SEBAGAI SUMBER PAKAN PADA BUDIDAYA SISTEM GANDA AZOLLA-LELE
}

\author{
Sudadi $^{1)}$ dan Suryono') \\ ${ }^{1)}$ Program Studi Ilmu Tanah Fakultas Pertanian UNS Surakarta \\ Email : sudadi_uns@yahoo.com
}

\begin{abstract}
Catfish farming is strongly influenced by the high price of feed, while azolla is a water fern that has a high nutritional value, can develop quickly and preferably by catfish as feed. The research aims to obtain the most appropriate combination treatment of Azolla inoculum dose and catfish seed size in dual system Azolla - catfish, which is able to provide the highest catfish yield. The experiments were performed in catfish ponds in completely randomized design (CRD) two factors, i,e azolla inoculum doses (250, 500 and $\left.750 \mathrm{gm}^{-1}\right)$ and head circumference size of catfish seed (3, 4 and $\left.5 \mathrm{~cm}\right)$. Dose of catfish seed is 2,000 head $/ \mathrm{m}^{2}$. Variables observed were azolla fresh weight and catfish fresh weight at harvest. Azolla inoculum and catfish seed deployed together in catfish ponds and feeding with concentrate feed for one month. Azolla and catfish harvesting is done on the same day using a sieve. Once drained, Azolla and catfish were weighed separately to determine the severity. Data were analyzed by $F$ test at the level of 95\%, followed by Duncan's multiple range test (DMRT) if any significance influence. The results showed that the higher the azolla inoculum number, the higher azolla yield. The larger the size of catfish seed the higher catfish consumption to Azolla. Catfish seed size more than $4 \mathrm{~cm}$ will cause an imbalance between the speed of consumption of Azolla by the catfish and the azolla growth rate, so that Azolla be devoured by catfish.
\end{abstract}

Keywords: Azolla, catfish, dual system, feed, integrated farming

\section{ENDAHULUAN}

Budidaya lele sangat dipengaruhi oleh harga pakan, sehingga membutuhkan upaya penyelesaian masalah yang dapat membantu dalam memecahkan masalah mahalnya harga pakan lele tersebut. Sementara itu, tanaman azolla yang merupakan tanaman paku air, memiliki kecepatan tumbuh dan biomasa serta nilai gizi yang tinggi. Sebagai contoh, azolla mengandung kadar protein antara 24-30\%. Kandungan asam amino essensialnya, terutama lisin $0,42 \%$ lebih tinggi dibandingkan dengan konsentrat jagung, dedak, dan beras pecah (Arifin, 1996). Pemanfaatan azolla yang dapat dibudidayakan di kolam lele ketika bibit lele masih kecil, merupakan wujud nyata dari penerapan keterpaduan antara peternakan lele dan azolla. Selain akan memberikan peningkatan penghasilan bagi peternak, maka juga akan meningkatkan kualitas lele sebagai produk organik, pengurangan biaya produksi, dan tidak mencemari lingkungan.

Azolla merupakan tumbuhan paku yang istimewa karena asosiasinya dengan ganggang hijau-biru Anabaena azollae menjadikannya mampu menambat nitrogen bebas (Khan, 1988; Lumpkin \& Plucknett, 1982), sehingga kandungan protein azolla cukup tinggi, yaitu berkisar antara 13-30 \% berat kering. Kandungan protein yang tinggi ini menjadikan azolla sebagai salah satu alternatif pakan ternak yang baik (Lumpkin \& Plucknett, 1982).

Upaya untuk memberikan solusi atas permasalahan mahalnya pakan lele perlu dilakukan melalui penelitian guna memperoleh kombinasi perlakuan azolla dan lele yang paling tepat dalam sistem ganda azolla - lele, yang mampu memberikan keuntungan usaha budidaya lele yang optimum.

\section{METODE PENELITIAN}

Metode penelitian yang dilakukan adalah budidaya sistem ganda azolla dan lele di dalam kolam dengan berbagai dosis inokulum azolla dan ukuran bibit lele. Bahan penelitian yang digunakan adalah inokulum azolla spesies Azolla microphylla, bibit lele ukuran panjang 3, 4 dan $5 \mathrm{~cm}$, dan pakan lele. Alat - alat yang digunakan adalan kolam lele, timbangan, saringan untuk panen azolla dan panen lele. Percobaan menggunakan rancangan acak lengkap dengan dua faktor yaitu dosis azolla $\left(250,500\right.$ dan $\left.750 \mathrm{gm}^{-1}\right)$ dan ukuran lingkar kepala bibit lele $(3,4$ dan $5 \mathrm{~cm})$. Variabel yang diamati meliputi berat azolla dan berat lele saat panen. Inokulum azolla dan bibit lele 
disebarkan bersama-sama pada kolam lele yang sudah diairi, selanjutnya dilakukan pemeliharaan lele dengan memberikan makanan berupa konsentrat pakan lele sesuai ukuran bibit lele. Pemeliharaan lele dilakukan selama satu bulan. Panen azolla dan lele dilakukan pada hari yang sama menggunakan saringan. Setelah ditiriskan, azolla dan lele ditimbang secara terpisah untuk mengetahui beratnya. Data yang diperoleh dianalisis dengan uji $\mathrm{F}$ pada aras kepercayaan $95 \%$ dan dilanjutkan dengan uji jarak berganda Duncan UJBD) apabila ada pengaruh yang nyata.

\section{HASIL DAN PEMBAHASAN}

Pada tabel 1, hasil menunjukkan baik inokulum azolla maupun ukuran bibit lele menunjukkan pengaruh yang sangat nyata terhadap berat azolla saat panen.. Demikian pula interaksi antar kedua perlakuan tersebut. Hal ini berarti bahwa jumlah inokulum azolla dan ukuran bibit lele harus diperhatikan dalam sistem budidaya ganda azolla - lele karena dapat mempengaruhi jumlah azolla yang masih tinggal, tetap hidup dan berkembang selama pemeliharaan lele. Hal ini penting karena kalau azolla habis dimakan lele maka tidak tersedia secara kontinyu selama masa pemeliharaan lele sehingga tidak dapat berfungsi sebagai pakan substitusi bagi lele. Akibatnya adalah tidak dapat menekan biaya produksi usaha lele.

Tabel 1. Hasil analisis ragam terhadap berat segar azolla saat panen

\begin{tabular}{lccccc}
\hline \multicolumn{1}{c}{ Source } & $\begin{array}{c}\text { Degrees of } \\
\text { Freedom }\end{array}$ & $\begin{array}{c}\text { Sum of } \\
\text { Squares }\end{array}$ & Mean Square & F Value & Prob \\
\hline Factor A & 2 & 1.710 & 0.855 & 41.9185 & 0.0000 \\
Factor B & 2 & 7.431 & 3.716 & 182.1380 & 0.0000 \\
Factor AB & 4 & 0.585 & 0.146 & 7.1663 & 0.0012 \\
Error & 18 & 0.367 & 0.020 & & \\
Total & 26 & 10.093 & & & \\
\hline
\end{tabular}

Coefficient of variation: $17.74 \%$.

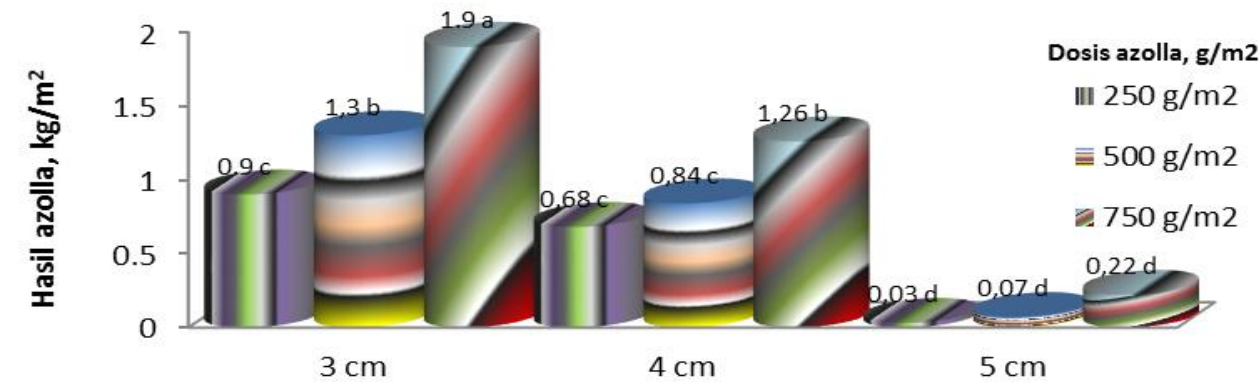

Ukuran bibit lele

Gambar 1. Pengaruh dosis inokulum azolla dan ukuran bibit lele terhadap berat azolla saat panen. Angka yang diikuti huruf yang sama menunjukkan tidak berbeda nyata pada uji Duncan aras kepercayaan $95 \%$.

Azolla dan ukuran bibit lele yang tepat akan dapat menjaga keseimbangan antara kecepatan tumbuh azolla dan konsumsi lele terhadap azolla sehingga azolla tidak habis dimakan lele, tetap tersedia sepannjang masa pemeliharaan lele. Ini akan mengurangi jumlah pakan lele yang diberikan dalam bentuk pakan konsentrat sehingga dapat mengurangi biaya pakan dan biaya usaha tani lele. Bila dilihat pada gambar 1 maka dapat dijelaskan bahwa dosis inokulum azolla sangat berpengaruh nyata terhadap berat azolla saat panen lele. Demikian juga pengaruh ukuran bibit lele dan interaksinya. Berat azolla meningkat nyata dengan meningkatnya jumlah inokulum azolla yang digunakan. artinya bahwa jumlah inokulum azolla yang tinggi cenderung menyebabkan tidak semua azolla habis dimakan lele sehingga terus bisa berkembang biak. Sebaliknya dengan meningkatnya ukuran bibit lele menyebabkan konsumsi lele terhadap azolla menjadi tinggi sesuai kebutuhan 
makanannya yang akan meningkat dengan meningkatnya ukuran tubuhnya. Akibatnya kecepatan tumbuh azolla tidak mampu mengimbangi kecepatan konsumsi lele terhadap azolla sehingga azolla (hampir) habis saat panen lele. Ukuran bibit lele $4 \mathrm{~cm}$ merupakan yang paling besar dimana azolla masih tetap berkembang sampai saat panen lele,

Pengaruh jumlah inokulum azolla maupun interaksi antara jumlah inokulum azolla $\mathrm{x}$ ukuran bibit lele tidak nyata pengaruhnya terhadap berat lele saat panen, sedangkan ukuran bibit lele sangat nyata pengaruhnya. Hal ini karena azolla disini masih relatif kecil perannya sebagai makanan pengganti konsentrat bagi lele, sehingga belum nyata pengaruhnya terhadap pertumbuhan lele. Berbeda dengan ukuran bibit lele yang secara sangat nyata mempengaruhi hasil lele saat panen.

Bila dilihat dari gambar 2 maka pengaruh ukuran bibit lele terhadap berat lele saat paenen masih terus meningkat secara linier. Ini berarti bahwa masih ada kemungkinan digunakan ukuran bibit lele yang lebih besar untuk menghasilkan karkas lele paling tinggi saat panen.

Tabel 2. Hasil analisis ragam terhadap berat segar lele saat panen

\begin{tabular}{cccccc}
\hline Source & $\begin{array}{c}\text { Degrees of } \\
\text { Freedom }\end{array}$ & $\begin{array}{c}\text { Sum of } \\
\text { Square }\end{array}$ & Mean Square & F Value & Prob \\
\hline Factor A & 2 & 0.035 & 0.017 & 0.9784 & \\
Factor B & 2 & 36.902 & 18.451 & 1035.4998 & 0.0000 \\
Factor AB & 4 & 0.036 & 0.009 & 0.4982 & \\
Error & 18 & 0.321 & 0.018 & & \\
Total & 26 & 37.293 & & & \\
\hline
\end{tabular}

Coefficient of variation: $3.49 \%$.

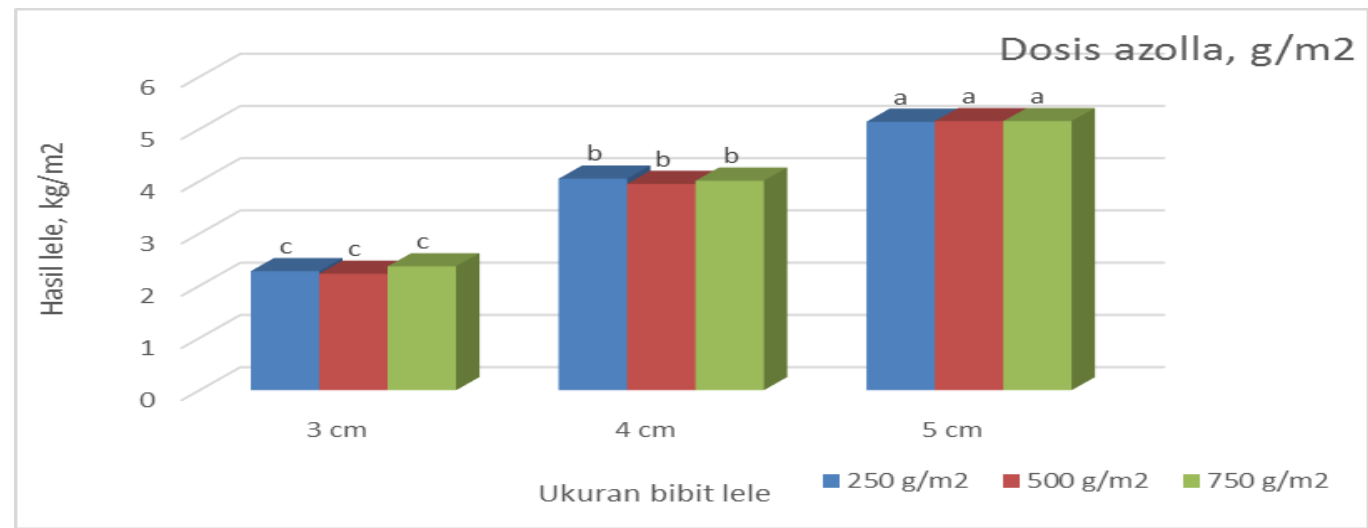

Gambar 2. Pengaruh dosis inokulum azolla dan ukuran bibit lele terhadap berat lele saat panen.

Angka yang diikuti huruf yang Sedangkan untuk perlakuan inokulum azolla, masih perlu untuk dikaji lebih dalam guna menemukan dosis optimum dan perlakuan yang dapat mempengaruhi pertumbuhan lele. Perlu dikaji komposisi yang optimum untuk pertumbuhan lele antara jumlah pakan konsentrat dan jumlah inokulum azolla yang digunakan.

\section{KESIMPULAN}

Jumlah inokulum azolla dan ukuran bibit lele mempengaruhi jumlah azolla yang masih berkembang sampai saat panen lele. Ukruran bibit lele $4 \mathrm{~cm}$ merupakan yang paling tinggi yang diperkenankan agar azolla tidak habis dimakan lele. Jumlah inokulum azolla yang optimum belum diperoleh artinya masih memungkinkan menggunakan jumlah inokulum azolla yang lebih tinggi.

Pengaruh ukuran bibit lele sangat nyata terhadap berat lele yang diperoleh saat panen, sedangkan inokulum azolla dan interaksinya dengan ukuran bibit lele berpengaruh tidak nyata. Ukuran bibit lele yang optimum belum diperoleh karena pengaruhnya masih bersifat linier. sama menunjukkan tidak berbeda nyata pada uji Duncan aras kepercayaan $95 \%$. 


\section{UCAPAN TERIMA KASIH}

Makalah ini merupakan hasil penelitian dari Hibah Penelitian Perkuatan Institusi Manajemen Rist Grup (MRG) dana PNBP UNS tahun anggaran 2015.

\section{DAFTAR PUSTAKA}

Anonim. 2010. Pola pembiayaan usaha kecil syariah (PPUK). Budidaya pembesaran ikan lele. BNI.

Anonim. TTG budidaya perikanan. budidaya ikan lele (Clarias). Kantor Deputi Menegristek Bidang Pendayagunaan dan Pemasyarakatan Ilmu Pengetahuan dan Teknologi Gedung II BPP Teknologi
Lantai 6, Jl. M.H. Thamrin 8 Jakarta 10340 Tel. 021316 9166 69, Fax. 021316 1952, http://www.ristek.go.id

Arifin, Z. 1996. Azolla pembudidayaan dan pemanfaatan pada tanaman padi.

Khan, M. M. 1988. Azolla agronomy. Bogor: IBS-UPLB and SEAMEAO Regional Center for Graduate Study and Research in Agricultural.

Lumpkin,T. A. and D. L. Plucknett. 1982. Azollaas green manure: use and management in crop production. Colorado: West View Press Inc 